\title{
PANDANGAN ALKITAB TENTANG OKULTISME
}

Minggus Dilla

minggusdilla@sttab.ac.id

\begin{abstract}
Occult practices have occurred since time immemorial, and even today occult practices cannot be separated from the lives of believers and humans in general. What are occult practices and how can occult practices occur and what are the impacts on human life. In this paper, the author will explain the biblical view of the occult and its ins and outs so that believers can know and be able to avoid various kinds of occult practices that are around us.
\end{abstract}

Key words: Bible view, Occult.

Abstrak: $\quad$ Praktik okultisme sudah terjadi sejak dahulu kala, dan pada masa sekarang pun praktik okultisme tidak bisa terlepas dari kehidupan orang percaya maupun manusia pada umumnya. Apa saja praktik okultisme itu dan bagaimana praktik okultisme dapat terjadi serta apa saja dampaknya bagi kehidupan manusia. Dalam tulisan ini, penulis akan memaparkan pandangan Alkitab tentang okultisme dan seluk beluknya sehingga orang percaya dapat mengetahui serta mampu menghindarkan diri dari berbagai macam praktik-praktik okultisme yang ada disekitar kita.

Kata kunci: Pandangan Alkitab, Okultisme.

\section{PENDAHULUAN}

Alkitab adalah sumber dari paham-paham atau ajaran-ajaran Kristen yang berkembang. Namun, dari beragam paham atau ajaran ini, orang percaya harus lebih bijak untuk memahaminya. Dari berbagai paham dan ajaran Kristen yang ada, tidak menutup kemungkinan lahir kepentingan sebagian oknum yang ingin menyesatkan iman orang percaya kepada Allah. Hal ini perlu untuk dikritisi lebih dalam Alkitab sering dihakimi oleh para theolog. Sering dipersoalkan dan diperalat demi kepentingan pribadi atau umat. Alkitab juga sering dipertentangkan dan diperdamaikan dengan Ilmu pengetahuan. Artinya ialah Alkitab dipandang sebagai sumber ilmu yang bisa juga dipahami hanya dengan ilmu pengetahuan. Stevri I. Lumintang menjelaskan hal ini dengan mengatakan bahwa Alkitab memiliki otoritas sendiri dan berbeda. "Otoritas Alkitab tidak bersifat kondisional, komunal dan kontekstual, karena otoritasnya adalah mutlak untuk semua orang di segala tempat dan waktu"1. Alkitab tidak bisa diposisikan berdasarkan kondisi, konteks yang ada dan tidak bisa berdasarkan kehendak komunitas tertentu. Tetapi Alkitab berdiri sendiri tanpa ada campur tangan atau intimidasi dari pihak manapun kecuali

\footnotetext{
${ }^{1}$ Stevri I.Lumintang, Keunikan Theologia Kristen di tengah Kepalsuan (Batu: Literatur PPII, 2010),
} 
kehendak Allah melalui penyataanNya sendiri. Alkitab tidak bisa berkompromi dengan apapun jika di luar konteks kebenaran Allah yang ilahi.

Dalam Alkitab, untuk menyebut roh jahat sering dipakai kata “iblis' dan "setan". Samakah kedua istilah itu? Atau berbeda? Sebutan yang berbeda itu sebenarnya menunjukkan apa? 1). Etimologi kata yang berbeda ${ }^{2}$. "Iblis" berasal dari kata Yunani "diabolos" berarti penuduh, pengumpat, pemfitrnah. "Setan", berasal dari kata Ibrani "shatan", berarti musuh. 2). Penekanan sifat yang berbeda. Pada waktu penulis Alkitab menyebut roh jahat, iblis, sebenarnya yang ingin ditekankan adalah sifat dari roh jahat yang senang menuduh, mengumpat, dan menyebarkan benih fitnah. ${ }^{3}$. Sedangkan waktu penulis Alkitab menyebut roh jahat itu setan, sebenarnya mereka ingin memberikan tekanan bahwa roh jahat itu musuh yang selalu menimbulkan benih permusuhan antara manusia dengan manusia, antara manusia dengan Allah. ${ }^{4}$ Jadi walaupun sebutannya berbeda, namun esensinya sama.

H. Soekahar, dalam Satanisme dalam Pelayanan Pastoral, menuliskan pengistilahan Iblis dan setan dari lingkup yang lebih luas:

(1). Pengertian Iblis menurut masyarakat Primitif.

Kepercayaan orang Indian di Amerika Utara, mereka mengenal apa yang disebut Ojibwa (chippewa) yang mendiami danau-danau besar. Ojibwa ini adalah manusia yang telah berubah menjadi makhluk raksasa yang sangat berbahaya dan pemakan manusia. Mereka percaya adanya roh-roh yang dapat merasuk manusia, ada roh-roh yang berbeda kekuatan gaibnya. $^{5}$

(2). Pengertian Iblis menurut Orang-orang Kuno.

Menurut orang Yunani kuno Daimones adalah mahkluk-mahkluk yang melampaui manusia, yang menjadi pengantara manusia dengan dewa yang mendiami daerah antara langit dan bumi. Menurut mereka orang-orang yang mati pada zaman keemasan akan berubah menjadi Daimones, yang mempunyai tubuh dan bersifat fana ${ }^{6}$

(3). Pengertian Iblis menurut Literartur Kuno.

Dalam literatur Yahudi kuno disebut-sebut mengenai Lilith. Lilith adalah iblis wanita yang muncul pada waktu malam. Lilith, menurut kepercayaan Yahudi adalah istri

\footnotetext{
${ }^{2}$ Op.Cit, Ekcyclopedia Americana, Vol. 9, h. 36.

${ }^{3}$ W.E. Vine, Expository Dicitonary of New Testament Words (Zondervan , Publishing House, 1952), h. 306.

${ }^{4}$ Ibid, h. 321.

${ }^{5}$ Loc.Cit, Encyklopedia Americana. Vol. 8

${ }^{6}$ Ibid.
} 
pertama Adam yang melarikan diri dari Adam dan menjadi iblis. Dia sering mencuri dan membinasakan bayi-bayi yang baru lahir dan membawa penyakit ${ }^{7}$.

Dalam literatur Babilonia kuno ada roh-roh jahat yang disebut Shedim, ialah berwarna hitam yang menuntut korban berupa putra putri mereka yang meneymbah kepadanya. Secirim, ialah iblis yang berbulu, sering mendiami ladang-ladang dan padang gurun. ${ }^{8}$

Dalam Perjanjian Lama, pernah disebut mengenai Shedim. Israel sebagai umat Allah dilarang keras mempersembahkan kurban kepada Shedim ini ( Ul.32:17; 18-19; Maz.106:37). Tuhan juga melarang UmatNya menyembah Secirim (Im. 17:17; Yes. 13:21; $34: 14)^{9}$.

\section{(4). Pengertian Iblis menurut Pengikut Zoroater.}

Menurut mereka, iblis adalah suatu kuasa yang menjadikan kegelapan. Dia adalah roh orang jahat yang berkuasa atas dunia bawah atau neraka, dialah yang mengambil nyawa orang-orang jahat yang mati.

(5). Pengertian Iblis menurut Orang Kristen Mula-mula.

Iblis dianggap oleh orang kristen mula-mula sebagai roh jahat yang sering mencobai manusia. Dewa-dewa kafir atau roh kekafiran adalah setan atau Iblis itu sendiri. Apabila seorang telah doibaptis dan masuk ke dalam persekutuan orang kristen, berarti telah terjadi pemutusan hubungan dengan kuasa setan. ${ }^{10}$

(6) pengertian Iblis menurut Orang Kristen Abad Pertengahan.

Dalam abad pertengahan, orang kristen melukiskan Iblis sebagai makhluk yang bertanduk, berekor, berambut, berkuku belah seperti dewa orang Yunani kuno yang di sebut Dewa Pan. Mereka menganggap filsuf-filsuf kuno adalah pengikut Iblis, ahli kimia dan astrologi dianggap sebagai orang yang melakukan pekerjaan dengan kuasa iblis. ${ }^{11}$

(7). Pengertian Iblis menurut Teolog Kontemporer.

Kierkegaard berpendapat bahwa yang disebut kerasukan setan adalah suatu keadaan di mana seseorang tidak bebas untuk melakukan yang baik. Keadaan ini akan nyata waktu yang baik itu bersentuhan dengan yang tidak baik. ${ }^{12}$

\footnotetext{
${ }^{7}$ J.W. Montgomery, Prof.,Demon Possesion (Minnesota: Bethany Fellowship, 1976), 33

${ }^{8}$ Ibid...., 32 .

${ }^{9}$ Ibid.

${ }^{10}$ Loc Cit, Americana Encyclopedia, Vol. 9.

${ }^{11}$ Ibid...., 9

12 Bernard Ramn, A Handbook of Ccontemporary Theology (Michigan: William. B.Eerdmans Publishing Company, 1974), 32.
} 
Menurut Karl Barth, iblis-iblis itu memang ada. Mereka membentuk kerajaan untuk melawan malaikat-malaikat yang baik dan para utusan Allah. Mereka akan menuju kebinasaan, menuhu neraka yang telah disiapkan bagi mereka. ${ }^{13}$

(8). Pengertian Iblis menurut Alkitab.

Alkitab memberikan data-data yang lengkap mengenai iblis atau setan dan tidak hanya spekulasi. Apakah Alkitab tentang iblis?

$>$ Iblis atau setan adalah mahkluk roh yang sungguh ada (1 Tawarikh 21:1; Ayub 1:6-12; Zakaria 3:1-2; I Petrus 5:8-9).

$>$ Iblis senang memaburkan benih yang jahat (Matius 13:39).

$>$ Iblis menjadi musuh orang beriman (I Petrus 5:8).

$>$ Iblis disebut Baalzebul, penghulu setan (Matius 10: 25; 12:24).

$>$ Iblis disebut Belial (II Korintus 6:15; artinya: yang menelan, tidak beruntung.

$>$ Iblis disebut penguasa kegelapan (Efesus 6:12).

$>$ Dia disebut roh najis (Matius 12:43)

$>$ Dia disebut si pencoba (Matius 4:3).

$>$ Dia disebut di jahat (Matius 13:19).

\section{PENGERTIAN OKULTISME}

Menurut Dr. E.P. Gintings, Okultisme berasal dari istilah "occult” artinya gelap, misterius, tersembunyi dan "isme" adalah ajaran. Okultisme adalah pengetahuan tentang gelap. ${ }^{14}$ Sedangkan Pondsius Takaliuang, menjelaskan istilah okultisme, berarti ajaran, paham, atau doktrin tentang hal-hal yang sifatnya rahasia, gelap, misterius dan tersembunyi, khususnya menyangkut kuasa kegelapan ${ }^{15}$. Stevri dalam bukunya Keunikan Theologia Kristen, mengatakan Okultisme dari istilah Latin "occultus" yang berarti: tersembunyi, rahasia, seram, gelap dan misterius. Lebih lanjut beliau mengatakan, pengertian harfiah ini dapat diterapkan secara umum untuk hal-hal yang berkaitan dengan pengalaman yang melampaui alat indera manusia (extrasensory), bersifat fenomenal. Pengalaman yang tidak dapat ditangkap secara utuh oleh mata, hidung, telinga, dan kulit bahkan tidak dapat diterangkan oleh alat indera ${ }^{16}$. Berkaitan dengan kemampuan extra manusia (extrasensory), E.P Gintings dalam bukunya Okultisme, menyebutnya dengan dua istilah, yakni: (1) Extra Sensory Influence (ESI), yaitu kemampuan extra dalam mempengaruhi seseorang seperti: black magic dan white magic serta sihir. (2). Extra

\footnotetext{
${ }^{13} \mathrm{Ibid} \ldots, 33$

${ }^{14}$ E.P.Gintings, Okultisme, Mewaspadai Okultisme Klasik dan Modern (Bandung: Bina Media Informasi, 2007), 13.

${ }^{15}$ Pondsius dan Susanna Takaliuang, Antara Kuasa Gelap dan Kuasa Terang (Batu: Dep. Literatur YPPII, 2004), Xvi

${ }^{16}$ Stevri I. Lumintang, Keunikan...., 376.
} 
Sensory Apparation (ESA), yaitu kemampuan seseorang untuk merubah dirinya atau merubah benda atau barang-barang di sekelilingnya, seperti: membuat dirinya tidak nampak, harimau jadi-jadian, babi ngepet, dll. ${ }^{17}$

Jadi dengan demikian dapat dikatakan, terlibat dengan okultisme, artinya terlibat dengan hal-hal yang gelap, yang rahasia, misterius, yang berhubungan dengan kuasa kegelapan atau supra alami. Sebaliknya terepas dari belenggu okultisme, berarti terlepas dari hal yang rahasia, tersembunyi, misterius, khususnya kuasa kegelapan serta semua praktek kuasa gelap tersebut. Bagi pengikut Kristus, hal-hal yang diajarkan dan dipraktekkan di dalam dunia okultisme itu bukanlah merupakan sesuatu yang gelap atau rahasia atau tersembunyi karena Firman Tuhan telah mengungkapkan apa yang sebenarnya terjadi dibalik praktek okultisme tersebut.

Kerajaan kegelapan merupakan suatu jaringan kerjasama yang rapih antara iblis dengan anggota-anggota kerajaannya, yaitu malaikat-malaikat yang telah jatuh ke dalam dosa atau biasa juga di sebut sebagai roh-roh jahat, itulah yang dimakssudkan Paulus dalam Efesus 6: 10-20, yakni roh-roh teritorial.

\section{PANDANGAN ALKITAB TENTANG OKULTISME DAN SELUK-BELUKNYA DALAM ALKITAB}

Kehidupan kekristenan merupakan kehidupan peperangan rohani (Efesus 6:12-13). Kitab Suci dari kitab pertama sampai kitab terakhir banyak berbicara tentang kenyataan, persoalan dengan okultisme atau kuasa gelap. Demonstrasai Iblis amat jelas dibeberkan di dalamnya. Iblis berusaha menipu manusia dengan caranya yang licik sehingga tanpa sadar kita telah terjebak di dalam perangkapnya. Dan kita harus memperhatikannya, karena Allah membukakan misteri okultisme atau kuasa kegelapan untuk diselesaikan dengan sungguh-sungguh.

Alkitab mengatakan, berhubungan dengan iblis dengan mempraktekan okultisme atau kuasa gelap sama dengan dosa penyembahan berhala. Dalam kenyataannya, keterlibatan dengan okultisme atau kuasa gelap terjadi sejak dalam kandungan sampai orang itu meninggal dunia. Bahkan sejak zaman purbakala sampai zaman modern terlibatan dengan okultisme sangat jelas, baik okultisme klasik maupun okultisme modern atau kontemporer. Stevri mengatakan, keterlibatan dengan okultisme menggambarkan kepalsuan dalam kekristenan yang terus ada dalam sepanjang sejarah kekristenan. ${ }^{18}$

\footnotetext{
${ }^{17}$ E.P.Gintings, Okultisme...., 38.

${ }^{18}$ Stevri Indra Lumintang, Keunikan...., 331
} 
Mengetahui sistem, eksistensi serta seluk beluk iblis sangatlah penting bagi kita. Oleh sebab itu pada bagian ini akan di bahas eksistensi setan atau asal usul setan, nama-nama setan, pekerjaan setan, bentuk keterlibatan dengan okultisame, nasib setan serta roh-roh jahat serta tempat persembunyian setan atau kuasa gelap.

\section{Eksistensi Setan Dan Roh-Roh Jahat}

Dalam kisah penciptaan dunia, dikatakan bahwa Allah melihat hasil ciptakanNya itu "sungguh amat baik" (Kej. 1:31), tentu saja hal ini mengindikasikan belum ada dosa dan kejahatan. Dalam dalam kejadian 3 dikatakan iblis menggunakan ular untuk menggoda Hawa dan lahirlah dosa pertama bersamaan dengan kejatuhan manusia,

Dalam teks yang lain menerangkan, ada malaikat-malaikat yang jatuh karena berbuat dosa (2 Pet. 2:4); ketidak taatan malaekat, menjadi sombong dan memberontak kepada Allah (Yudas 6). Dua teks ini memberikan gambaran yang kuat bahwa malaikatmalaikat yang tidak taat serta memberontak kepada Allah adalah para malaikat yang jatuh, seperti yang tertulis dalam Yesaya 14: 12-15; Yehezkiel 28:13-17. Diciptakan Allah sebagai malaikat (Kol.1:16). Sejajar dengan Mikhael (Yud. 1:9). Sempurna penuh hikmat dan maha indah (Yeh. 28:13). Ditempatkan dekat kerub di hadirat Allah (Yeh. 28:14). Dijinkan Allah untuk masuk sorga (Ayub 1:7; 2:2). Jatuh dari llangit bagaikan kilat (Luk. $10: 18)$.

\section{Nama-Nama Setan}

Alkitab menyingkapkan panjang lebar nama-nama setan menyangkut juga sifatnya, seperti yang ditulis Pondsius Takaliuang, dalam Buku Pedoman Pelayanan Pelepasan menjelaskan secara rinci, sebagai berikut:

A. Nama-nama yang menyangkut sifat-sifat jahat:

1. Iblis (Mat. 4:1, 10), diabolos, pemfitnah, pengumpat, setan, lawan, musuh.

2. Si pencoba (Mat.4:3).

3. Roh Dusta (! Raj. 22:22-23); pendusta, bapa segala dusta (Yoh.8:44).

4. Pembunuh Manusia (Yoh. 8:44).

5. Roh najis (Wah. 18:2; Zak.13:2).

6. Roh Penyesat (1 Tim.4:1).

B. Nama-nama menyangkut hal yang menakutkan.

1. Maut ( Ibr.2:14-15; Wah.6:8).

2. Hantu (Mat.14:26; Luk. 24:37-39).

3. Roh kekacauan (Yes. 19:14).

4. Roh ketakutan (2 Tim. 1:7).

5. Roh perbudakan (Rom. 8:15).

6. Raja kedasyatan (Ayb. 18:14). 
C. Nama-nama menyangkut keinginan tubuh yang tidak wajar.

1. Roh perzinahan (Hos. 4:12; 5:4).

2. Roh penidur (Yes. 29:10).

D. Nama-nama menyangkut penyakit tertentu

1. Roh kelemahan (Luk. 13:11).

2. Roh yang membisukan (Mrk. 9:17).

3. Roh yang menyebabkan orang menjadi tuli, buta, bungkuk (Mrk. 9:25; Mat. 12:22; Luk.13:11).

4. Roh dibelakang sakit ayan (Mat. 17: 15, 18).

E. Nama-nama menyangkut praktek okultisme langsung.

1. Roh tenung (Kis. 16:16).

2. Roh peramal (Im. 19:31; 20:6; Ul. 18:11; Yes.8:19; 19:3).

F. Nama-nama menyangkut jenis hewan tertentu.

1. Naga (Wah. 12:3).

2. Ular (2 Kor.11:3).

3. Singa (1 Pet.5:8).

4. Lewiatan (Yes. 27:1).

5. Katak (Wah.16:13).

G. Nama-nama yang menyangkut situasi zaman.

1. Roh dunia (1 Kor.2:12).

2. Ilah zaman (2 Kor.4:4).

H. Nama-nama menyangkut kepercayaan yang anti Kristus.

1. Roh anti Kristus (1 Yoh.4:3).

2. Roh yang menyesatkan (1 Yoh.4:6); penyesat (1 Tim.4:1).

I. Nama-nama yang menyangkut penyamaran khusus.

1. Malaekat terang (2 Kor.11:14).

2. Malaekat-malaekat (Mat.25:41; Wah. 22:8-9).

3. Dewa-dewa asing (Kej. 35:2,4).

J. Nama-nama menyangkut penguasa di udara, atmosfir.

1. Bintang timur (Yes. 14:12).

2. Putera fajar (Yes. 14:12).

3. Bintang-bintang (Yud.1:13).

4. Ratu Sorga (Yer.7:18).

5. Tentara langit (2 Taw.33:3).

6. Roh-roh jahat di udara (Ef.6:12).

K. Nama-nama menyangkut situasi politik.

1. Pemerintah-pemerintah (Ef.6:12).

2. Penguasa-penguasa (Ef. 6:12).

3. Abadon/apolion (Wah. 9:11).

4. Pemimpin Kerajaan Persia (Dan. 10:20).

5. Raja Tirus (Yeh.28:11-19).

6. Legion (Mrk. 5:9).

L. Nama-nama menyangkut penyembahan kepada dewa-dewi khusus.

1. Allah lain (Kel. 20:3). 
2. Sukot-Benot (2 Raj.17:30), "kemah-kemah anak-anak perempuan"

3. Nergal (2 Raj.17:30), "pahlawan, dewa perang, wabah, dunia bawah".

4. Asima (2 Raj.17:30) "serangan"

5. Nibhas (2 Raj.17:31), "pemberontak", manusia berbentuk singa.

6. Tartak (2 Raj.17:31), "penghulu kegelapan”, berbentuk keledai.

7. Adramelek (2 Raj. 17:31, "raja api”, bayi dibakar untuk dia.

8. Anamelek (2 Raj. 17:31), "Anu adalah raja”, dewa langit.

9. Asyera (2 Raj. 18:19), "lurus", dewa kesuburan istri Baal.

10. Asytoret (2 Raj. 23:13), "bintang” dewi kesuburan.

11. Baal (2 Raj.23:7), "tuan" sadis dan mengerikan.

12. Baal-Berit (Hak. 8:33), "tuan perjanjian" dewa cuaca.

13. Baal-Peor (Bil. 25:3), "tuan dari lubang" disembah dengan hubungan seksual yang bebas.

14. Baalzebub/Baalzebul (2 Raj. 1:2; Mat. 12:24), "tuan dari lalat" penghulu setan.

15. Bel (Yer. 51:44), "tuan".

16. Kamos (1 Raj. 11:7), "penakluk" anak dikorbankan untuk dia.

17. Kewan; sakut (Am. 5:26), dewa bintang.

18. Dagon (1 Sam. 5:2), "ikan" berwajah manusia, berbadan ikan.

19. Artemis/Diana (Kis. 19:35), "keselamatan", keamanan.

20. Gad (Yes. 65:11), "pasukan" dewa nasib baik.

21. Yupiter/Zeus (Kis. 14:12, 13), dewa tertinggi dilangit.

22. Milkom (1 Raj. 11:5), "raja mereka" sama dengan molokh.

23. Meni (Yes. 65:11), "nasib” dewa nasib.

24. Hermes/Merkuri (Kis. 14:12), dewa perdagangan, olah raga, seni berpidato dan pencurian.

25. Molokh (Yes. 57:9), "raja" anak dikorbankan baginya.

26. Nebo (Yes. 46:1), "nabi" pelindung pendidikan dan pelajaran.

27. Nehustan (2 Raj. 18:4), ular tembaga Musa yang disembah.

28. Nisrok (2 Raj. 19:37), "burung elang besar"

29. Refan (Kis. 7:43), "kekayaan"

30. Rimon (2 Raj. 5:18), "buah delima" dewa matahari yang membuat buah delima masak.

31. Tamus (Yeh. 8:14), "tunas" dewa padang rumput, hewan, air dan tumbuhtumbuhan.

32. Apis (Yer. 46:15) dewa sapi jantan.

33. Amon (Yer. 46:25; Nah. 3:8), "pembantu" dewa orang mesir.

34. Merodhak (Yer. 50:2), "penyembah Baal" di Babel.

35. Dioskuri (Kis. 28:11), dewa kembar, Kastor dan Poluks, dewa perang, yang juga menolong para pelaut pada waktu angin topan, kalau mereka memberikan persembahan kepada dewa-dewa itu. ${ }^{19}$

${ }^{19}$ Pondsius Takaliuang, Pedoman Melepaskan Orang dari Ikatan Kuasa Gelap, (Batu: Dep. Literatur YPPII, 1989), 6-11. 


\section{Pekerjaan Setan Dan Roh-Roh Jahat}

Alkitab menginformasikan, pekerjaan setan atau kuasa gelap itui menyangkut banyak hal. Dalam buku pedoman pelayanan pelepasan, Pondsius menguraikannya pekerjaan setan atau okultisme adalah sebagai berikut:

A. Pekerjaan menyangkut Firman Tuhan.

1. Memutar balikan Firman Allah (Kej.3:1-5).

2. Mengambil Firman Allah dari dalam hati (Mrk. 13:19).

3. Mengutip Firman Allah untuk menyesatkan (Luk.4:9-12).

4. Membelokan manusia daripada memperhatikan Firman (Kis.13:6-12).

5. Mengirim rasul-rasul palsu (2 Kor.11:13-15).

B. Pekerjan menyangkut mengirim orang jahat.

1. Mengirim orang untuk berbuat jahat (Ayub 1:12-15).

2. Untuk membunuh (Ayub 1:12, 17).

3. Menebarkan pengikutnya dimana-mana (Mat.13:38-39).

4. Menempatkan dukun-dukun/tukang-tukang sihir (Kis. 13:6-12).

C. Pekerjaan menyangkut berbuat mujizat.

1. Mengirim api dari langit (Ayub. 1:12, 16).

2. Mengirim angin ribut (Ayub 1:12, 18, 19).

3. Memberikan kuasa besar (Mrk. 5:2-5).

4. Menyaingi mujizat dari Allah (Kel. 7:20-22).

5. Membuat tanda-tanda ajaib (2 tes.2;9).

6. Menghidupkan oatung sehingga berbicara (Why.13:15-16).

D. Pekerjaan menyangkut penyakit.

1. Mengirim penyakit yang parah (Ayub 2:6-7).

2. Merusakkan tubuh manusia (1 Kor. 5:5).

3. Menyiksa (1 Sam. 16:14-16).

4. Merasuk (Mrk. 1:23).

5. Membuat bungkuk dan tak bisa berdiri tegak (Luk. 13:11).

6. Membuat bisu dan tuli (Mat.12:22).

7. Membuat tubuh kejang (Mrk. 9:17-18).

E. Pekerjaan menyangkut hal mencobai orang beriman.

1. Membelokkan dari kehendak Allah (Mat. 16:21-23).

2. Mencoba (Mat. 4;1, 3).

3. Menampi (Luk. 22:31).

4. Menyamar sebagai malaikat terang (2 Kor. 11:14).

5. Memenjarakan orang beriman (Why. 2:10).

6. Memberi usul yang kelihatannya baik tapi berbahaya (1 Taw. 21:1).

7. Menawarkan kekayaan dan kemuliaan dunia (Luk. 4:5-8).

8. Mengacaukan suami istri dalam soal seks (1 Kor.7:5).

9. Menyuruh untuk menyalahgunakan kedudukan (Luk. 4:3-4).

F. Pekerjaan menyangkut hal berbuat dosa.

1. Masuk dalam hati manusia untuk berkhianat (Yoh. 13:27).

2. Masuk dalam hati manusia untuk berbuat dusta (Kis. 5:3). 
3. Menyesatkan janda-janda muyda dalam soal seks (1 Tim. 5:15).

4. Menyesatkan banyak orang (1 Tim. 4:1-2).

5. Memberikan pikiran buruk (Yak. 3:14-16).

G. Pekerjaan merusak hidup manusia.

1. Mengambil keuntungan dari kesedihan orang percaya (2 Kor. 2:11).

2. Menuduh, mendakwa (Za. 3:1-3; Why. 12:9-10).

3. Menggelapkan hati (2 Kor.4:4).

4. Membuat orang tidak mengenal kebenaran, tidak sadar suka melawan (2 Tim. 2:25-26).

H. Pekerjaan lainnya.

1. Bertengkar dengan Mikhael berebutan mayat Musa (Yud.1:9).

2. Mengeliliiunbgi dunia (Ayub. $1: 7 ; 2: 2$ ).

3. Mendirikan 'gereja setan' (Why. 2:9; 3:9).

4. Memegang kuasa maut, walaupun terbatas (Ibr. 2:14); Why. 1:17-18).

5. Masuk ke dalam hewan (Mrk. 5:13).

6. Melindungi wilayah-wilayah tertentu atau teritorial (Bil. 14:9). ${ }^{20}$

\section{Nasib Setan Dan Roh-Roh Jahat}

Kendatipun setan berkuasa tetapi tidak memiliki otoritas. Alkitab mengatakan semua pekerjaan setan harus seijin Allah. Iatelah dikalahkan oleh Yesus Kristus di kayu salib. Lebih lanjut Pondsius menulis nasib kuassa kegelapan adalah:

1. Dibuang dari hadirat Allah (Yeh. 28:16).

2. Dibinasakan oleh kerub Allah (Yeh. 28:16).

3. Dihukum (Kel.12:12).

4. Dijatuhkan dari langit (Luk. 10:18).

5. Dilucuti Tuhan Yesus di salib dan melalui kebangkitanNya (Kol. 2:15).

6. Pekerjaannya dihanvcvurkan Tuhan Yesus (1 Yoh.3:8).

7. Dikalahkan dan dibuang oleh orang beriman dimana-mana (Yak. 4:7; Mrk.16:17).

8. Akan diikat selama seribu tahun (Why. 20:1-3).

9. Akan dihakimi oleh orang beriman (1 Kor. 6:3).

10. Akan disiksa dalam api neraka selama-lamanya (Why. 25:41; Mat. 8:28-29; Why. 20:10).

11. Tidak akan bisa bekerja dan merusak dunbia lagi, lenyap dari dunia baru (Why. 21:1-8). ${ }^{21}$

Setan adalah roh yang sangat menyedihkan, tanpa harapan, dan tidak pernah berhasil, dan akhirnya hidupnya adalah kebinasaan kekal. Sejak awal aktivitasnya dalam dunia, pada peristiwa di taman Eden, setan dan pengikutnya sudah dihukum (Kej. 3:15),

\footnotetext{
${ }^{20}$ Pondsius Takaliuang, Pedoman ...., 12-14.

${ }^{21}$ Ibid..., 16-17.
} 
bahwa Tuhan mengadakan permusuhan antara setan dengan perempuan (Hawa), dimana ketrurunannya akan meremukan kepalanya (binasa), demikian Stevri dalam tulisannya. ${ }^{22}$

\section{Tempat Persembunyian Okultisme Atau Kuasa Gelap}

Kembali Pondsius dalam bukunya mengungkapkan tempat persembunyian kuasa gelap, adalah persembunyian dalam praktek okultisme langsung.

1. Dalam keluarga yang mempraktekan okultisme.

a). Keluarga yang masih kafir (1 Pet.1:18; Yos. 24:2-3).

b). Keluarga yang mencampur adukan Tuhan dengan berhala/sinkritisme (Kej. 31: 19, 30; I Raj. 35:13; 16:31-32; II Raj. 13:6; I Raj. 18:18; Yos. 24:15; Ul. 13:6-11; II Raj. 17:41).

2. Dalam penggunaan mantera-mantera atau jampi-jampi.

a). Oleh orang-orang yang membenci Tuhan (Kel. 7:10-12; Ul. 18:10; Maz. 58:6).

b). Oleh orang-orang yang mencampur adukan Tuhan dengan iblis (Kis. 19:13-16).

3. Dalam utusan-utusan atau hamba-hamba setan.
a). Dukun dukun perempuan (Yeh.13:18).
b). Juru-juru tenung (Yer. 27:9; 29:8; Ul. 13:1-5).
c). Tukang-tukang ramal (yer. 27: 9).
d). Tukang-tukang sihir (Yer. 29:9; Kel. 22:18; Why. 21:8).
e). Para pemanggil arwah (2 Raj. 23:24).
f). Imam dewa asing (2 Raj. 23:5, 20).
g). Ahli jampi (Dan. 2:2, disebut juga astrologi, Kis.7:11-12).
h). Penyembah berhala (Why 21:8).
i). Pendusta-pendusta (1 Tim. 4:1-3).
j). Anti Kristus (Why 13:1-8; 1 Yoh. 2:18-19, 22).
k). Nabi paksu dan Rasul palsu ( Ul. 13:1-5; 2 Kor. 11:13-15)
1). Penrlaah dan pemantera (ul. 18:10-11).

4. Dalam benda-benda Iblis.
a). Patung (Kel. 20:3-5; Ul. 4:16-18).
b). Tugu berhala (Kel. 23:24).
c). Allah tuangan (kel. 34:17).
d). Tiang-tiang berhala (Kel. 34:13).
e). Batu berukur ( Bil. 33:52).
f). Mezbah untuk iblis (Ul. 12:3).
g). Batu-batu licin dari sungai (Yes. 57:6).
h). Tali-tali azimat (Yez. 13:18).
i). Tongkat (Hos 4:12).
j). Buku-buku okultisme (Kis. 19:19).
k). Benda-benda rohani yang dikeramatkan, efod, nehustan (Hak. 8:28; 2
Raj.18:4).

${ }^{22}$ Stevri Indra Lumintang, Keunikan ...., 372-373. 
5. Dalam penyembahan/hubungan langsung dengan setan/iblis.
a). Mempersembahkan korban untuk jin-jin (Im. 17: 7).
b). Memanggil Allah lain (Kel. 23:13).
c). Mempersembahkan korban untuk roh jahat (U1. 32:17; Yer. 7:18).
d). Meminta petunjuk kepada orang-orang mati (Yes. 8:19).
e). Minta petunjuk kepada arwah (Yes. 8:19; Im. 19:31).

6. Dalam ilmu-ilmu gelap, ilmu rahasia.

a). Mantera, sihir, ramal, tenung, filsafat kosong, mistik, tabu, ajaran sesat, cara hidup sia-sia ( Bil. 23:23; Yes. 49:9; Ul. 18:10; 1 Tim.4:1-3; Kol. 2:8; 1 Pet. 1:18; 2 Tim. 2:17-18).

7. Dalam penyembahan kepada benda-benda angkasa.
a). Menyembah matahari, bulan, bintang (Ul. 4:19; 17:3).
b). Segenap tentara langit (Ul. 4:18; 17:33).
c). Dewa matahari, bulan, rasi bintang-bintang (2 Raj. 23:5, 11).

8. Dalam tempat-tempat keramat.
a). Pohon keramat, pohon rimbun, bukit pengorbanan (Yes. 1:29-30; Ul. 16:21; 2 Raj. 16:4; Im. 26:30).
b). Gunung-gunung, kuburan-kuburan, gua-gua (Ul. 12:2; Yes. 57:7; 65:4).
c). Kuil-kuil, bekas temoat-tempat rohani (1 sam. 31:9-10; 1 Kor. 8:10; Yes. 48: 13; Am. 3:14)

9. Dalam kehidupan seks bebas.
a). Pelacuran bhakti, di tempat penyembahan berhala (1 Raj. 15:12, 22:47; Yer. 2:20; 3:6, 13).
b). Praktek inkubus/sukubus, perkawinan dengan yang tidak seiman (Yud. 1;6-7; Kel. 34:15-16; Hak. 3:6).

10. Dalam mencampur adukan kepercayaan / sinkristisme.
a). Tuhan dan patung, Tuhan dan dagon, Tuhan dan agama buatan sendiri (Hak. 17:18-20, 30-31; 1 Sam. 5:2-7; 1 Raj. 12:25-33).
b). Bernubuat demi baal (Yer. 2:8).
c). Membiarkan ajaran dari iblis dalam jemaat (Why. 2:20).
d). Tuhan dan ileh bangsa-bangsa, Tuhan dan mantera (2 Raj.17:29-32; Kis.19: 13-15).
e). Gereja setan (Why 2:9; 3:9).

11. Dalam adat istiadat lama (2 Raj. 17:8, 33-34, 40; Kol. 2;8).

12. Dalam dosa-dosa tertentu.
a). Kedurhakaan dan kedegilan (1. Sam. 15:23, raja saul).
b). Dusta, materialisme, mencuri, perzinahan ( Kis. 5:1-4; Yoh. 12:6; Hos. $4: 12 ; 5 ; 4)$.
c). Kesombongan, kecurangan, amarah (Yes. 14;14-15; Yeh. 28:14-16; Kej. 4:6-7).

13. Dalam hewan tertentu (ular, babi), Kej. 3:1-5; Mrk. 5:11-13).

14. Dalam nama-nama khusus, kota khusus, musik (Dan. 1:7; 4:8-9; Why. 18:2, 23; Dan. 3:1-4; 5-7, 10). 
15. Dalam tawaran kekayaan, kemuliaan diluar Tuhan, tawaran kuasa (Luk. 4:6; Mat. 4:8-9).

16. Dalam praktek okultisme modern, seperti; dimandikan oleh "orang pintar"; minum air khusus; memakai ilmu kebal; hipnotis; yoga; telepati; magnetisme; sihir cinta; berjalan diatas api, telekinesis, clairvoysnce, musik underground, dll. ${ }^{23}$

\section{Akibat Keterlibatan Dalam Praktek Okultisme}

Setan menggunakan segala macam cara untuk menyerang dan menjatuhkan orang percaya. Setan tidak main-main dengan rencananya, karenanitu serang iblis itu seutuhnya terhadap seseorang, yakni berkaitan dengan:

1. Rohani, menyakibatkan: orang tersebut tidak tertarik dengan perkara rohani; buta terhadap perekara rohani; tidak merasa bersalah melakukan dosa.

2. Mental, rasa takut dan gelisah; kemunduran mental; gangguan jiwa.

3. Fisik, bisa lahir cacat atau menjadi cacat; bisa mengalami sakit turunan.

4. Moral, suara hati tidak berperan; cenderung melanggar aturan.

5. Sosial, merassa gelisah bila berada diantara orang percaya; cenderung merusak hubungan dengan sesama, dalam keluarga dan dalam komunitas apapun; merasa tidak layak/tak berguna.

6. Hukuman kekal, terjadi bagi setan dan juga para pengikutnya, termasuk orang yang praktekan kuasa gelap tersebut (Why. 20:9-10; $21: 8){ }^{24}$

7. Akibat untuk diri sendiri: menjadi najis (Im. 17:7), menjadi sakit (Luk. 13:11), sesat (2 Taw. 33:1-11), menjadi tambah jahat, menjadi gelap/suram (Yes. 8:19-21), susah dalam hidup (Maz. 16:4), menjadi kacau (Yes. 19:1, 14), pahit hati (Kis. 8:923), mengalami ketakutan yang tidak wajar (Ibr. 2:14-15), menjadi sial dan terhukum (Kel. 20: 3-5, bisa bunuh diri (Yoh. 13:27; mat. 27;4-5).

8. Akibat untuk keturunan: terkutuk dan mengalami kehidupan sia-sia ( Kel. 20:3-5; I Pet. 1:18).

9. Akibat untuk kekekalan: tidak akan mewarisi kerajaan Allah (Gal. 5:19-21); masuk dalam penyiksaan kekal (Why. 21:8; 22:15).

10. Akibat lainnuya: hidup tercerai berai (Za. 10:2); tidak tahan menghadapi pencobaan (Yes. 57:6-9, 13); Firman Tuhan tidak akan masuk dalam hati (Mat. $13: 4,19){ }^{25}$

11.

\section{PENUTUP}

Dari semua penjelasan di atas dapatlah di mengerti bahwa iblis atau setan itu memang ada yang bekerja secara teritorial sekalipun mata jasmani kita tidak melihatnya. Jika kita sebagai dan mempercayai Alkitab sebagai Wahyu Allah bagi manusia, maka kita harus mengenal si iblis sebagaimana yang dikatakan oleh Wahyu Allah tersebut, bukan

\footnotetext{
${ }^{23}$ Pondsius Takaliuang, Pedoman ...., 18-25

${ }^{24}$ Stevri Indra Lumintang, Keunikan ...., 413-414

${ }^{25}$ Pondsius Takaliuang, Pedoman...., 26-27
} 
menurut tradisi setempat, tafsiran teolog ataupun pandangan iman kepercayaan lain, demikian Soekahar berpendapat ${ }^{26}$. Dengan demikian dapatlah di fahami bahwa kuasa gelap itu bejerja secara teritorial dan berusaha menguasa semua sistem yang ada dalam alam semesta. Bekerja secara global dan menjadi tantangan besar bagi iman kristen. Stanley W. Heath menyebutnya dengan "keberhalaan di sepanjang zaman", dimana bangsa-bangsa kafir memperilah sesuatu dengan mencari makna di belakang alam fana, seperti penyembahan gunung berapi, $\mathrm{dsb} .^{27}$

Kemenangan Kristus di kayu salib menjadi jaminan kemenangan orang percaya atau gerejaNya terhadap kuasa gelap. (Mat. 4:1-14; Roma 5:12-19). Alkitab katakan kepada semua orang yang percaya kepadaNya diberikan otoritas atas setan dan roh-roh jahat oleh karena keselamatan yang Yesus telah berikan. (Kis. 26:18; Luk. 10:17-20; II Kor.4:4; Ef. 2:1-3; Kol. 1:13). Sejak orang itu percaya maka Roh Kudus akan memampukan untuk berjalan dalammkekuatan FirmanNya dan terus berjaya dalam kemenangan saat menghadapi pemerangan rohani. (1 Pet.5:8-9). Kelengkapan senjata rohani yang dijanjikan Tuhan Yesus bagi orang percaya menjadi kekuatan juga bagi orang percaya mengalahkan kuasa gelap. (Ef. 6:11-18).

\footnotetext{
${ }^{26}$ H. Soekahar, Satanisme ...., 1-5

${ }^{27}$ Stanley W. Heath, Ilah Zaman Ini, (Yogyakarta: Yayasan ANDI, 1996), 2
} 


\section{DAFTAR PUSTAKA}

E. Vine, W. (1952). Expository Dicitonary of New Testament Words, Zondervan: Publishing House

Lumintang, Stevri, I. (2010). Keunikan Theologia Kristen di tengah Kepalsuan, Batu: Literatur PPII.

P. Gintings, E. (2007). Okultisme, Mewaspadai Okultisme Klasik dan Modern, Bandung: Bina Media Informasi.

Ramn, Bernard. (1974). A Handbook of Ccontemporary Theology, Michigan: William. B.Eerdmans Publishing Company.

Takaliuang, Pondsius dan Susanna Takaliuang. (2004). Antara Kuasa Gelap dan Kuasa Terang, Batu: YPPII.

(1989). Pedoman Melepaskan Orang dari Ikatan Kuasa Gelap, Batu: Dept. Literatur YPPII.

W. Heath, Stanley. (1996). Ilah Zaman Ini, Yogyakarta: Yayasan ANDI

W. Montgomery,J. (1976). Demon Possesion, Bethany Fellowship, Minnesota. 